\title{
Keeping race at bay: familial DNA research, the 'Turkish Community,' and the pragmatics of multiple collectives in investigative practice
}

\author{
Irene van Oorschot ${ }^{1,3}\left(\left[-\right.\right.$ Amade $^{\prime}$ 'charek $^{2} \odot$
}

Accepted: 1 August 2021 / Published online: 27 October 2021

(C) The Author(s) 2021

\begin{abstract}
In this contribution, we analyze the recently adjudicated Milica van Doorn rape and murder case. In this case, committed in 1992, no suspect could be identified until investigatory actors employed familial DNA searching in 2017. Crucially, familial DNA typing raised the possibility of ethnic and racial stereotyping and profiling, particularly against the background of the first case in which familial DNA typing was used in the Netherlands: the Marianne Vaatstra case, which from the start had been marred by controversy about the ethnicity of the unknown perpetrator. In our analysis, we show how criminal justice actors managed this potential for racialization through strategically mobilizing and carefully managing multiple collectives. Drawing on the notions of multiplicity and non-coherence, we show we do not only empirically trace the situated ethics and pragmatics of familial DNA research in this specific case, but we also develop a theoretical argument on the multiple and non-coherent character of race itself and its attendant ethical, political, and methodological possibilities and obligations.
\end{abstract}

Keywords Familial DNA $\cdot$ Race $\cdot$ Genetics $\cdot$ Forensics $\cdot$ Material semiotics

Perhaps it is wrong to talk about it [race] as 'a concept' rather than as a group of contradictory forces, facts and tendencies.

W. E. B. du Bois, Dusk of Dawn (1940) So, this is the question, how do non-pure practices that are simultaneous practices of purification actually work? How do these logics hold themselves together - or not? J. Law et al., Modes of Syncretism: Notes on Non-Coherence (2014)

Irene van Oorschot

vanoorschot.irene@gmail.com

1 Life Sciences \& Society Lab, KU Leuven, Leuven, Belgium

2 Department of Anthropology, University of Amsterdam, Amsterdam, The Netherlands

3 Teteringen, The Netherlands 


\section{A momentous occasion: the trial of Hüseyin A.}

It is a cold November morning when $\mathrm{I}^{1}$ take a seat in the Court's public benches. As an observing researcher, I am a stranger in this company: around me, the victim's family members, both close and distant, are softly talking about the impending trial of Hüseyin A, the alleged rapist and murderer of Milica van Doorn. Milica was raped and murdered in 1992, yet police investigators had not been able to identify a suspect until 2017, when a familial DNA search led them to the suspect's door.

In Court, Hüseyin A. is telling his side of the story. He had a secret relationship with Milica van Doorn, he claims. That's why his DNA was found on her body - but he didn't rape or kill her. His lawyer emphasizes the possibility of another, as of yet unknown assailant. The Court seems rather unconvinced; when they probe Hüseyin A. for specific details about this relationship - when did it start? How did you usually meet? Why didn't her friends know about you? - his answers are vague and evasive. His lawyer cannot be happy with his performance, I think to myself as I recollect the conversation I had with him just prior to the hearing. In an almost off-handed manner, Hüseyin's lawyer had informed me that their whole defense strategy would not contest the DNA itself but only 'how it ended up there,' that is, inside of Milica's body. The DNA materials, after all, are 'pretty definitive.'

Two weeks after the Court hearing, I find myself in court again - this time, to observe the adjudication of the case. Following the first hearing, commentators in the media have tended to treat the case as pretty definitive. Hüseyin A.'s defense is generally framed as non-convincing, and - as his lawyer has sighed, the DNA is generally thought to be 'pretty definitive'. Yet there is some tension regardless as the presiding judges enter the room and commence the reading of their verdict. Narrating the criminal investigation and pointing out the crucial role of familial DNA searching, the presiding judge finds Hüseyin A. guilty. He is sentenced to a 20 -year prison term.

In this piece, we closely follow the development of this Milica van Doorn case in order to develop a theoretical and methodological argument about the complex and fractured realities of 'race' in forensic investigation. Examining the ways police investigators sought to zoom in on an unknown suspect by means of ancestry DNA and familial DNA searching, we highlight the way that these novel forensic technologies are mobilized in actual practices. Examining the production of multiple and non-coherent 'suspect collectives' (Cole and Lynch 2006) in forensic practice, we show how police investigators actively managed the discriminatory and racializing potential of these technologies. Drawing on the notion of multiplicity as developed by Mol (2002) and an emphasis on the

1 When narrating the dynamics in Court, the 'I' refers to the first authors of this article. 
pragmatic management of such multiplicities in practice (see Law et al. 2014), we conceptualize three distinct ways by which criminal justice actors managed different collectives in practice: 1. Caring for non-coherence, a strategy evident throughout the police investigation; 2. Taming non-coherence, a strategy the public prosecutor elected in Court, and 3. Erasing non-coherence, a strategy mobilized by the Court in its eventual verdict. We show that while the public prosecutor came rather close to enacting and reproducing racial understandings of human difference, both police investigators and the Court instead successfully kept 'race at bay' by emphasizing the non-coherent character of the multiple collectives mobilized over the course of the investigation. In so doing, we also seek to develop a methodological sensitivity to the politically and empirically fraught realities of race in forensics, emphasizing the necessity of both critique and-crucially-care (Cf. Puig de la Bellacasa 2017).

The trial of Hüseyin A., the event that concerns us here, was momentous for a variety of reasons. First, of course, it was a cathartic moment for Milica's family and friends, who had had to wait 27 long years for what we can only assume is only an impoverished form of relief. But it was also momentous because this case is the second case in the Netherlands in which familial DNA typing was successfully used to apprehend an unknown perpetrator. As such it closely tracked two significant developments in the field of forensics in the Netherlands and beyond. On the one hand, the Dutch government had adopted a law in 2012 that specified and detailed the legitimate uses of familial DNA typing, hence broadening prosecutorial and forensic possibilities. On the other hand, the Netherlands also had a reservoir of experience and expertise that the investigators could draw on as they had previously employed familial DNA typing successfully in the controversial Marianne Vaatstra case. As Marianne Vaatstra was raped and killed by slicing her throat and as her body was found in the vicinity of a center for asylum seekers, commentators in the media were quick to speculate that her murderer would have been a non-Dutch person, an asylum seeker. Mobilizing pre-existing controversy over the establishment of the asylum center and suggesting that slitting a throat is a 'non-Dutch' way of killing (Jong and M'charek 2018; Parool, 27 June 2001; Trouw, 16 October 1999), the public's eye became fixated on this center for asylum seekers. However, when the public prosecutor asked a forensic laboratory in Leiden to research the suspect's biogeographic ancestry in 2000 on the basis of DNA collected at the crime scene, the results pointed towards a man likely of North-Western European ancestry. This was later affirmed when a large DNA dragnet, in which the perpetrator participated voluntarily, led to a direct match with the DNA materials found on Marianne Vaatstra's body.

Where this first case was mired in controversy about the ethnic identity of the unknown perpetrator from the very start and involving incendiary racist claims about the perpetrator (Jong and M'charek 2018; M'charek et al. 2020), such concerns were much more subdued, if at all present, in the Milica van Doorn case. Indeed, if incendiary claims about the suspect's non-Dutch status proliferated in the Marianne Vaatstra case, such claims were largely marginal in the Milica van Doorn case, even if biogeographic ancestry tests were suggesting a possible Turkish descent. While some incidental commentators (not journalists) on twitter framed the 
Milica van Doorn rape and murder as a failure of 'multicultural society,' there were no broader efforts to link this specific crime with the suspect's ethnic background in the media. Given the fact that the Dutch public debate has, over the last 20 years, moved towards a more right wing 'realism' on the 'problems' that inhere in 'multicultural society' - which is to say that Islamophobia and racism, often couched in culturalist or nativist terms, have become a more visible and audible social presence (see e.g., van Reekum 2014; Balkenhol et al. 2016; Essed and Hoving 2014; Wekker 2016) — this lack of outrage is striking indeed. Nor did commentators on the left pay much attention to the case, even though it was the second case in which familial DNA searching was used in the Netherlands.

The eventual guilty verdict, then, may not have surprised many. More puzzling is the fact that throughout the investigation, and especially the last phase, the Milica van Doorn case did not generate the intensity of xenophobic sentiments and concern. How did this happen? What kept the Milica van Doorn case from turning into another 'fire object' (Jong and M'charek 2018), involving incendiary mobilizations of race and racism? How, in other words, was race kept at bay?

In this article, we seek to take this question seriously-not as a way to speculate on the waning of racism or xenophobia in Dutch society (there is little evidence of that) - but rather to unearth the ways in which police actors, having learned from the Marianne Vaatstra case, employed familial DNA searching in the case of a supposedly Turkish suspect. As our analysis shows, among police investigators, the potential for this case to evolve into a similarly incendiary case was very much on their mind throughout the final stages of the investigation and translated into a series of actions taken to ensure that the Turkish community in and of itself was not further stigmatized and racialized. In other words, they aimed to keep that dreaded thing 'race' at bay. Analyzing the choices made by these investigative actors, we suggest that these investigative actors managed to do so by strategically and selectively mobilizing the non-coherent collectives that shaped their inquiry, from phenotypical witness statements to DNA research. By showing how police investigators mobilized multiple and non-commensurable collectives in practice, we further suggest that this non-coherence and multiplicity offers police investigators the practical possibilities to keep race at bay, thus, turning non-coherence into an asset for the investigation. As such, this article traces the mobilization of familial DNA searching beyond the forensic lab and analyzes how and where the collectives enacted do or do not congeal into 'race.' Our analysis seeks to further social studies of forensics, demonstrating the precise means by which the potential discriminatory role of familial DNA typing was managed in forensic and legal practice.

In order to do this, we first situate our contribution within the field of STS and the study of race and forensics, and outline our conceptual approach. This conceptual approach highlights multiplicity and non-coherence, and functions as a heuristic to empirically attend to the way multiplicities and non-coherences are managed in practice (part 2). After that, we offer some methodological notes by reflecting on our sources and situating ourselves as scholars writing about race and police practices in the tumultuous early 2020s (part 3). Then, we move on to an empirically driven analysis of the multiple and non-coherent collectives that were mobilized throughout the Milica van Doorn case, emphasizing in particular the way police investigators 
managed these multiplicities and in so doing, kept race at bay (part 4). In the concluding section, we offer some methodological and conceptual recommendations for further study (part 5).

\section{Race, forensics, and modes of managing multiplicity}

The relationship between genetics and race is complex and fraught. While the Human Genome project of the 1990s was explicitly introduced as a way to attend to our common humanity - that which makes us the same-genomics as a discipline has tended to concern itself largely with genomic differences between populations (M'charek 2005; Reardon 2005; Liphardt 2017). In that capacity, genomics has been a crucial instrument in the production and mobilization of novel collectives organized around (aspects of) biology, leading to a revival of the concept of biosociality (Rabinow and Rose 2006). A consequence, genomics has required us to reckon once again with the reality and relevance of biological race. While genetic researchers may be quick to point out that race is an artifact of a racist past and that genetics allows us to move beyond such crude and illusory constructions of difference, scholars within social studies of science have approached such claims with fitting caution. Genetics has for instance been pointed to as active in the novel molecularization of race (Duster 2006; Fullwiley 2007), reinscribing and naturalizing differences at a molecular level. Moreover, race may appear once again in medical research as a proxy (Foster and Sharpe 2002) for presumed to be underlying, 'real' biological differences in certain genetic propensities to disease. And biological race is never quite far away in techniques of sampling in population genetics (Fujimura and Rajagopalan 2011) and forensic genetics (Duster 2006), where race informs and shapes genetic knowledges yet is officially relegated to the realm of 'bad science'. In studies of these practices, the performative and productive character of genomics in shaping and defining collectives has taken center stage (Duster 2006; Ossorio 2006; Goodman et al. 2012, Fullwiley 2007; Koenig et al. 2008). They show that biology allows for the production and mobilization of differently circumscribed collectives and populations (M'charek 2000; M'charek \& Wade 2020), and consequently leads to what John Hartigan has described as processes in which "race is gaining in reality" (Hartigan 2008), both within the lab and within the societal fields and spheres within which such knowledges circulate.

Indeed, when such genetic knowledges travel beyond the lab, they not only may reify dominant understandings of national selves and others (Wade et al. 2014; Santos and Maio 2004; Fortier 2011; de Rooij et al. 2015) but also lead to novel articulations of indigeneity and belonging (Reardon and TallBear 2012). Next to medical research, forensic genetics has been an important practice within which genetic productions of collectives are translated and mobilized 'beyond the lab,' that is, in actual criminal investigation. Itself positioned precariously and sometimes awkwardly between law and science, criminal forensics is first and foremost a pragmatic field of knowledge that aims to assist investigation. Often characterized by a focus on an unknown individual-the unknown suspect-forensics has been characterized as a practice of making and remaking connections between specific collectives 
and individuals in practice (Cole 2020; M'charek and Wade 2020). Genomics has significantly reshaped forensic research, introducing novel ways to zoom in on and identify individual suspects. At the same time, race is just around the corner in such practices as well. Biogeographic ancestry searching, for instance, can be understood to reify associations between bodies and spaces and, hence, enact race (Gannett 2014) while familial DNA searching may run the risk of further stigmatizing and racializing specific families and communities (Machado and Granja 2020; Toom and M'charek 2011). Moreover, the novel techniques of DNA phenotyping represent a return of the surface in contemporary genetic articulations of race, with commercial actors like Parabon NanoLab generating facial sketches of unknown suspects based on DNA (M'charek 2020; M'charek and van Oorschot 2019), which sketches have the capacity to interact with and strengthen both social and judicial associations of crime with the phenotype (see van Oorschot 2020).

From this wealth of studies - to which we do not have the space to truly do justice here-there are two important lessons to learn. One, genetic forensics is a field of practice that has the particular and complex power to reinscribe difference at the biological level. In other words, in its use of genetic materials and in its necessary mobilization of genetically circumscribed collectives, forensics tends to be marked by a haunting specter of race. Here, race can be understood as an absent presence (M'charek 2014), hovering around the edges of practices as a ghost from a never entirely suppressed past (M'charek and van Oorschot 2019; see also Hall 1987), leading to significant societal as well as academic concern. Not rarely does forensic genetics attract criticism and concern for the way it reproduces and naturalizes difference, racializing both individual suspects and the communities or collectives to which s/he is said to belong. Where criminal justice systems reproduce racial power structures and perpetuate forms of racial dominance, such critiques are a necessary counterweight to celebratory techno-optimisms that characterize certain forensic fields (e.g., Kayser 2015). Fascinatingly, our case, as we will show, represents a moment that engages with the discriminatory potential of forensic genetics, and familial DNA typing in particular. It demonstrates how this potential lead investigators to make specific choices in order to 'keep race at bay' during the criminal investigation.

Second, standing out from this wealth of studies in particular is a lesson of a more conceptual kind. In their empirical rigor and emphasis on specific and situated practices, these studies have also demonstrated that there are multiple ways to enact different collectives (van Oorschot and M'charek forthcoming). In other words: collectives of human beings are not naturally given but emerge out of specific ways to lump and split, enact sameness, and difference. This also means that biological race, much biological disease in the seminal analysis of Annemarie Mol (2002), is not a singular thing. Rather, it is produced in different settings, and such enactments of biology are contingent on specific affordances of specific technologies (Nash 2005; Palmié 2007; Nelson 2008). Biological race, then, is a material semiotic and relational assemblage, enacted into being in specific contexts and practices (M'charek 2013). What is enacted here as a collective, let alone biological race, is not necessarily how it is constituted there (M'charek 2000; M'charek and Wade 2020). These observations raise the further empirical question how and where such 
multiple collectives are, or are not, brought into relation with each other, and how in and through these relations, these collectives may or may not congeal into 'race,' and 'gain in reality' (Hartigan 2008). In the following, then, we wish to reflect conceptually on this multiplicity, questioning what questions may arise when we take it seriously.

\section{Multiplicities and non-coherence: a pragmatic approach}

As we know from Mol's (2002) account of multiplicities in medical settings, multiplicities do not necessarily yield problems for the practices in which they emerge. Clinicians and pathologists may, in their concerns with diagnosing atherosclerosis for instance, be technically and practically dealing with different objects, but their practices need not be disturbed by such multiplicities at all. It is only in some instances that they must find ways to explicitly manage such multiplicities and to create some form of coherence, for instance when they speak to each other at conferences, or when they are discussing a specific case. The fact that things do not cohere, then, tends to be a theoretical problem for researchers rather than a pragmatic problem for those we study. However, in some instances, non-coherence does ask for a response in practices. Building on this recognition that things, objects, and entities do not necessarily cohere, Law et al. (2014) point out that there are many ways by which multiplicity or non-coherence may be managed in practice. Loosely drawing on the notion of syncretism, which asks attention for the "processes that combine or perhaps secure the temporary coexistence of practices and doctrines from a variety of dissimilar religious backgrounds," (2014, p. 176) Law et al. seek to understand how, if we have 'never been modern' (Latour 1993) or always have been nature-culture cyborgs (Haraway 1991), we have dealt with-or not dealt with-the hybrid, the impure, and the multiple in actual practice.

In order to understand how such non-coherence is managed, Law and colleagues provide a non-exhaustive, speculative list of modes of non-coherence, distinguishing between denial, domestication, separation, care, conflict, and collapse. Firstly, multiplicity may be denied to exist—but such denial, crucially, takes work to perform a reality of non-multiplicity. Or, multiplicity may be domesticated, in which the qualitative differences between non-coherent logics and worlds are 'tamed' (2014, p. 180), rendered comparable, quantified, so that their difference is smoothed over. Or, yet again, non-coherence may be dealt with by keeping non-coherent entities or logics apart, by separation; after all, it is only in their meeting that non-coherencies typically start to present troubles. Care may also be a way to attend to and manage non-coherence: then, non-coherence is explicitly recognized and presents itself as a problem that must be negotiated and cared for. And as we learn from Puig de la Bellacasa, care requires active work and practice, not just moral posturing (2017). Of course, conflict between non-coherent or multiple logics and entities is always a possibility, and tends to accompany political and public deliberations on multiple and conflicting conceptions of the good. Collapse, lastly, is perhaps the most pragmatic mode of non-coherence, in which non-coherence does not even appear as a problem 
to be managed. Differences between logics and entities do not register as different at all; pragmatically, there is effectively no non-coherence to be managed.

While our discussion of non-coherence here might appear rather abstract, the point Law and colleagues seek to develop is that such non-coherencies are endemic in everyday practices, and that practices of managing (or denying!) non-coherence may take different shapes and forms. As their analysis shows, denial, domestication, or collapse are powerful ways to render non-coherence coherent. However, separation, care, and conflict, within which non-coherence is allowed to exist, are also important ways of managing non-coherence. We contend that these insights on non-coherence offer a powerful heuristic to empirically attend not only to the production of multiple collectives in forensic practice, but also-and here our contribution lies- to the way such multiple, non-coherent collectives are managed in practice. They offer us the conceptual vocabulary to analyze how, over the course of one investigation, multiple collectives were strategically mobilized in the search for an unknown suspect. Crucially, they also offer a way to understand how, out of these multiple collectives in the Milica van Doorn case, race never quite congealed into a fixed reality. In other words: this conceptualization of pragmatic modes of managing non-coherence helps us understand how race was kept at bay.

Before we, however, turn to our empirical analysis in part 4, we elaborate on our methodological choices as well as our own positioning vis-à-vis the field of race and criminal justice in the following.

\section{Methodologically situating ourselves: tracing legal cases and tackling police dealings with race}

In order to develop our argument, we have sought to carefully trace the steps taken in the Milica van Doorn case, drawing on reports in the media, observations and conversations in Court, interviews with associated actors within the investigation on the forensics and the police side, and last but not least, the official written verdict as published by the Dutch judiciary online. In so doing, we draw on this variety of sources to sketch the outlines of a timeline, discern various steps and various mobilizations of evidence, and to trace the case from crime scene to verdict. However, tracing of cases is not a straightforward manner, even though our presentation of the case here in narrative necessarily introduces a certain linearity (M'charek 2014) that contrasts with the winding character of the case as it developed over time. Endemic to the social study of legal case-making - and indeed to the way legal practices themselves enact procedure and time (van Oorschot 2014a, 2018) - this linearity is a post-hoc performative effect of the narrative form. Hence, it must be borne in mind that over the years, the case ran into various dead-ends and obstacles. We pay less attention to these various dead-ends in the investigation, unless they have been instrumental in reorienting police actors' attention towards exploring alternative modes of inquiry. Indeed, we actively have to resist this linearity, as-we will show-it tends to involve a specific mode of managing non-coherence, one that skims over the different ways of doing differences between the multiple collectives that were mobilized over the course of the investigation. Such a reading, then, is one 
that would deny precisely the multiplicities that we seek to trace here. As such, our intervention can be read not only as an effort to retrace the investigation, but also as a way to stay with multiplicity in order to attend to the work it does-and the work that takes place around it.

Another aspect that shapes our account of the case is the fact that judicial deliberation itself is methodologically and legally inaccessible: when judges come together to deliberate on the case behind the scenes, they are held to strict secrecy (in Dutch, this is poetically called the 'secret of the chamber' [geheim van de raadkamer]). While verdicts cannot be treated as a veracious reflection of actual deliberations behind the scenes they nevertheless provide access to the judicial framings and understandings of not only the crime itself, but also of the legal evaluation and mobilization of evidentiary materials. Nor have we been able to access the official dossier, which in the Dutch context functions as the prime transporter (and transformer!) of evidentiary and forensic reports, rendering the facts of the case available to decision-makers in the here and now of the court session (van Oorschot 2021) and organizing and coordinating a variety of legal work practices (Van Oorschot 2014b; Wissink and van Oorschot 2021). ${ }^{2}$ However, this piece does include unique information about the behind-the-scenes strategies and deliberations taking place within the police investigation, particularly through an in-depth conversation with one of the task force members.

Situating ourselves in the broader sense also means that we have to attend to the fraught societal and political struggles taking place around criminal justice and race at the moment of writing. The Black Lives Matter movement and the protests throughout the US against police violence have renewed the call for prison abolition and defunding, or indeed abolishing, the police apparatus. European cities have also witnessed a series of protests in support of Black Lives Matter. While these developments were not on the radar of the police investigators during the Milica van Doorn investigation for the simple reason they had not happened yet, they nevertheless are an important societal context for us to become responsible to-be able to respond-in our writing. In this context, too, our engagement with the way police investigators actively made use of biological proxies of race in their use of biogeographic ancestry testing and familial DNA searching runs the risk of appearing as an apology for police dealings with race. This is certainly not our purpose. Instead, we insist precisely on the empirical and political value of 'staying with the trouble' (Haraway 2016): of closely attending to the way police officers encounter, manage, and-as we show-end up navigating the 'trouble' represented by the specter of race throughout their investigation. In this way, we seek not an external position of critique, but draw on Puig de la Bellacasa's conceptualization of care as a methodological and conceptual sensibility (2017). In tracing the care police investigators took to 'keep race at bay,' then, we are similarly aiming to care for these practices ourselves, even and perhaps especially where and when they take us into uncomfortable and compromised realities. As such, we do not suggest that the Dutch police force is generally exemplary in its dealings with race and racism-it most decidedly

\footnotetext{
2 The verdict has been appealed by the defense, for which reason this case file is not accessible.
} 
is not-rather we empirically engage with one instance in which police investigators asked themselves critical questions about their own dealings with race and made choices we are tracking and analyzing here.

\section{Mobilizing multiplicities: partial mappings and modes of non-coherence}

In the following, we first seek to trace what multiple 'suspect collectives' (Cole and Lynch 2006) were mobilized over the course of the investigation by means of a timeline, after which we turn to our analysis.

\section{Individuals and collectives of interest: a reconstruction}

In 1992, the initial search for the unknown suspect in the Milica van Doorn was shaped by and large by one specific witness description. This witness description included a reference to a 'singing Turkish man on a bicycle,' who had been seen cycling near the vicinity of the crime on the night Milica van Doorn was raped and murdered. Witness descriptions such as these, while contested both within legal practice (van Oorschot 2021) and outside of it (Walker 2003), are endemic in criminal investigation. For their efficacy such witness descriptions depend on a specific understanding of witnessing on the one hand, and a specific conception of human difference on the other. For these witness descriptions to do the work they are supposed to do, human differences must be understood to be legible on the surface of the body, and-importantly-legible at a glance. Such witness descriptions are themselves, then, active in the enactment of a specific phenotypical understanding of difference, drawing on racial modes of seeing and recognition (M'charek 2020). At the same time, this witness description also situated this unknown suspect in a specific context and milieu: having been seen singing on a bicycle, it was deemed likely that this 'Turkish man' was not a recent migrant to the Netherlands but rather someone who was socialized into cycling in the Netherlands. As such the description also evokes specific forms of labor migration, especially from Turkey and North Africa that took place over the 1960s and 1970s. Here, we see this particular dynamic of individuals and collectives quite clearly: in pointing to a specific individual, it also articulates and mobilize a collective of Dutch-Turkish men.

Further steps in the investigation, e.g., looking for a suspect among Milica's family or friends, would yield few results. Similarly, although DNA material assumed to belong to the suspect, was found on Milica's body, it did not yield a match within the database as it existed 1992 and after. Yet the DNA was retained for possible later use.

Indeed, the next big step in the investigation that took place over 2007 and 2008 entailed DNA. Given the various dead-ends the police had run into, the choice was made to draw on recent advances in biogeographic ancestry testing. Previously, the DNA found on Milica's body was used to exclude people from a pool of suspects in her vicinity (e.g., neighbors, friends, family). When these 
attempts did not yield a match, investigators had to start taking the scenario that the suspect was not from Milica's 'circle' more seriously. This opened up a reeling wealth of possibilities, as now the perpetrator, not from Milica's 'circle,' could be almost anyone. In order to narrow down these possibilities, police investigators turned to the unknown suspect's DNA materials to test these for biogeographic ancestry. The techniques used to construct the suspect's biogeographic ancestry were, at that time, quite new. Yet these had been used and practiced with before, in the aforementioned Marianne Vaatstra case, where the results pointed to a suspect from Northern European descent (which contrasted sharply with popular suspicion focusing on a nearby center for asylum seekers, see Jong and M'charek 2018; de Knijff 2006). In the Milica van Doorn case, the analysis focused on two types of $\mathrm{Y}$ chromosomal markers: short tandem repeats (STRs) and single nucleotide polymorphisms (SNPs). While the exact haplogroups used in the Lab's analysis remain to this day confidential information, we do learn from the verdict that this information pointed to 'a Turkish and perhaps Northern-African' suspect. This information was then used, in 2008, to set up a DNA dragnet focused on men from Turkish and Northern-African descent living in the vicinity of the crime. Participation in this dragnet was wholly voluntary. Hüseyin A., who did receive an invitation, declined to participate. Again, the police were no further in apprehending him; nor did this step in the investigation yield further clues.

Over 2013 and 2014, police actors formed a specifically designed team to take a fresh look at the case, particularly to inquire whether it was possible to use the previously done biogeographic ancestry pointing to a Turkish or North-African man in further familial DNA typing. Composed of five members, it included various experts ranging from a criminologist evaluating the case at the level of various scenarios and forensic experts. This team also regularly invited external experts, bringing in expertise on recent developments within forensic genetics, or on the demographic as well as cultural composition of the Dutch-Turkish community. The timing of the establishment of this team was shaped by the 2012 adoption of a novel Dutch law regulating the forensic use of familial DNA typing, which opened up possibilities for criminal investigators to employ it under stringent conditions. Indeed, this law specified that familial DNA typing could only be used as an ultimum remedium, that is: when all other options have been exhausted. As familial DNA typing brings specific families and sometimes communities to the fore as objects of forensic and investigative concern, Dutch legislators reasoned that may clash with the prohibition on targeting people for investigation based on their descent (afkomst). The use of familial DNA typing, then, had to meet the strictest conditions of subsidiarity, proportionality, and had to have a practical and feasible 'chance of success.'

The specially designed team, then, had to carefully navigate this law, specifying and justifying the way they would ensure subsidiarity, proportionality, and the practical chance of success well in advance. Within these deliberations, a variety of concerns played a role: "You have to take into account how it [familial DNA searching] is going to land in the public perception", one of the team members tells us for instance. Especially as these novel technologies may play into broader 
societal fears of surveillance and function creep, the choice for familial DNA typing had to be carefully motivated. This member of the team, thus, reasons:

So as for the societal acceptance, right, and the [possibility of] stigmatization: how does that weigh up against proportionality and transparency, or how might it [the proposed familial DNA research] be actively harmful?

The problem, then, would not only be of an ethical or political character, but also pragmatic:

What if people don't want to participate in future investigations? Or maybe, in the worst case, it generates so much unrest that the 2012 law will be revoked - I mean, we are after all talking about sensitive data!

However, there was also the more specific danger of further marginalizing an already marginalized Turkish community in the Netherlands. Not only could it lead to 'unrest within the Turkish population in the Zaanstad or even in the Netherlands' as a whole; it could also lead to 'stigmatization' and 'doing violence to a population':

How much violence do we do to such a population? And does that have any proportional relation to the benefit of solving the crime?

Here, the specific phrasing of our informant highlights the criterion of proportionality. Crucially, in this case, the possible stigmatizing effects of opting for familial DNA testing were explicitly evoked to tease out not just the justification but indeed the very choice for familial DNA typing. On the one hand, the team wanted to find firm footing and needed expert opinion on the 'firmness' of the initial biogeographic ancestry data: 'is this information sufficiently scientifically validated?' But this potential for stigmatization and violence called for a critical and reflexive approach throughout the investigation as well.

Indeed, these concerns with stigmatization significantly affected both the timing of the project and the practical delineation of a target population. At first, the police had drawn a circle of five kilometers around the crime scene, which, coupled with information about nationalities from the municipal records, generated about 7000 people. In the previous Marianna Vaatstra case, a similar amount of people had been asked to participate, so this number was not in principle deemed impossible. It was also an attractive possibility as it would involve a large number of people, hence maximizing the practical chance of success (one of the three important criterions). However, it was at that moment in time that the 2016 (supposedly) Gülen-led coup against Erdogan was strongly reverberating through the Dutch-Turkish community (NOS, July 16 2016), heightening conflicts between their respective supporters, in one case even leading to the temporary closure of a primary school associated with the Gülen movement in The Hague. Mobilizing the expertise of a social scientist with a significant track record of studying the Dutch-Turkish community, the police carefully sought ways to navigate this internally diverse community that-to their surprise- 'was no community.' Confronted with not only religious, but also political cleavages within the Turkish 
community, the police narrowed down their selection, making it as targeted as possible, emphasizing proportionality over the practical chance of success. Drawing on the scenario reconstruction involving a man on a bicycle and assuming that the suspect must live in the immediate vicinity of the crime scene, they decreased the 'circle' around the crime scene, which strategy ended up yielding 133 men.

The potential for stigmatization of this 'community that is no community, furthermore, also informed their method of generating interest and cooperation among the community. Not only did the police keep a strong check on official media communications about the case, they also spoke with different representatives within the Turkish community directly to garner support. Moreover, the day before the 133 men would receive an official letter explaining familial DNA searching and asking for their cooperation, the Dutch crime-watch show Opsporing Verzocht devoted a long section of their program to the case, uniquely subtitling it in Turkish, while the letter itself included an accessible explanation of familial DNA searching. Going from door to door with especially instructed police officers and offering people to give a sample of their DNA in the privacy of their own home, the police aimed to maximize people's willingness to participate. On December 5 2017, Arnoud Kal, DNA specialist at the Dutch forensic Institute (NFI) realized that one of the DNA profiles of the 132 men who were swabbed bears marked similarity to that of the unknown suspect: "the suspect must be his brother!" (de Volkskrant, December 12 2018). Indeed, while Hüseyin A. himself did not participate, his brother did, leading the police, after a 25-year long, winding inquiry, straight to his door.

\section{Managing non-coherence: caring, taming, and erasing}

Having discussed the steps in the investigation so far, we have encountered multiple ways of enacting and mobilizing different suspect collectives. While the witness description enacts a phenotypically circumscribed collective of 'Turkish-looking' men, the biogeographic ancestry testing of 2007 and 2008 instead enacts a natureculture collective of people tied together by virtue of biological descent as well as histories of migration, pointing in the direction of people with biogeographic 'roots' in both the Mediterranean and more recent labor migration trajectories. Last, familial DNA research, based on this previous biogeographic ancestry testing, enacted yet another nature-culture collective, consisting of people who, at the time of the crime, were thought to have a meaningful 'connection' with the surrounding area. These collectives are multiple, constituted with help of different technologies and involving different delineations of possible collectives and not necessarily coherent. They do not simply map onto each other in any simple sense. People who are not, biogeographically speaking, from an area we could call 'Turkey' may nevertheless look 'Turkish' to a witness. People with much older migration histories may not be known or registered as having a double nationality.

These very different collectives may, or may not, be brought into relation with each other. The question, with Law et al (2014) in mind, then, is: How did various actors over the course of the investigation manage this non-coherence? How were 
relations made between these multiple collectives - and where and when were such relations not made, or actively unmade? In the following, we contrast the actors' approaches to non-coherence, showing in particular how the investigative strategy adopted by the police represents a strong attempt not to deny or gloss over noncoherence but to actively keep it in play, in order, we suggest, to keep race at bay. We also discuss how both the public prosecutor and the Court itself in turn managed these non-coherences.

\section{The police: caring for non-coherence}

In the police dealings with these multiplicities and non-coherencies we can discern a mode of managing non-coherence organized around care. Here, we have to understand care not only as a moral stance-as in: caring about-but precisely as a practice, a matter of caring for (Puig de la Bellacasa 2017). As we have seen, the police investigators were well aware of the differences between the collectives mobilized in a witness description, the 2007-2008 biogeographic ancestry testing, and the final familial DNA typing. If the witness description implicated a collective of 'Turkish-looking' men with probably ties to the Netherlands (he was seen riding a bike), the biogeographic ancestry enacts and implicates a collective of men whose biogeographic ties may be of a much earlier date (going back hundreds of years and evoking the Ottoman empire), and includes possible North-African men as well. Meanwhile, the familial DNA testing mobilizes a collective ordered around familialbiological ties evoking a collective of Turkish migrants living in particular parts of the Netherlands. However, police investigators were also to realize that what they thought of as a homogenous 'Turkish community' was in fact a collection of diverse and contrasting political affiliations and cultural orientations. In effect, this meant that both the delineation of a suspect collective and the communications and outreach strategy required careful navigating and managing. Their practices of care had two dimensions in particular: one, of carefully relating multiplicities to arrive at as small a sample as possible; second, of carefully avoiding making relations between genetics, the Turkish community, and crime. in order to delineate a target population, the police had to carefully combine and relate multiplicities to each other: mapping biogeographic ancestry data (from 2007 to 2008) as well as the witness description onto each other and combining this with scenario-specific informationthe fact of the bike- they produced a narrowed down collective of interest: Men of Turkish descent who at the time of the crime lived in its vicinity. Here, care requires a careful negotiating of multiplicities: hence the mobilization of both police- and forensic expertise in minimizing this target population while maximizing the 'practical chances of success.'

For Law et al (2014), the modality of care operates on the basis of an acknowledgment of non-coherence. Care happens when non-coherence is recognized as a problem to be carefully managed. However, in this case, too much coherence between biological and socio-cultural collectives would also represent a problem for the police, as that would needlessly 'biologize' a collective that was already marginalized and criminalized in society. While on the one hand, then, care included 
an attempt to map collectives onto each other, it was also comprised of efforts to keep them from cohering too well. One way the police did so is through its highly controlled public communication strategy. The Opsporing Verzocht episode is a case in point: subtitled in Turkish, it goes to great lengths to explain how, on the basis of biogeographic ancestry testing, a witness statement, and the geographic specificities of the area, this specific selection of men was made. The rather explicit message, here, is that the police is certainly not targeting all Turkish men or the entire community. Secondly, the highly individualized strategy of going door to door to sample DNA, eventually chosen over a reliance on public settings, emphasized and interpellated individuals as individuals rather than reducing them to a collective. Examining this strategy closely, then, care emerges not only as a practice of relating multiplicities and non-coherent collectives - but also of keeping these collectives apart, as well as disassembling collectives once again into individuals. In other words, care, here, involved orchestrating different collectives in such a way that the phenotypical and the biological did not start to cohere too well. Strategies of individualization as well as public explanation and accountability helped police investigators to do so.

\section{Public prosecutor and court: taming versus erasing non-coherence}

Fascinatingly, however, both the public prosecutor and the Court opted for different ways to manage this non-coherence. In court, two rivaling modes of managing non-coherence stand out in particular: taming non-coherence by an appeal to precision, as adopted by the public prosecutor, and separation by erasure by the Court. The public prosecutor, firstly, connected the multiple and non-coherent collectives explicitly in its requisitoir - its extended framing and construction of the facts of the case at the closing of the proceedings in Court. There, the prosecutor makes a case for Hüseyin A.'s guilt by emphasizing not only the eventual DNA match following the familial DNA research, but also and crucially that very first witness description of 1992 identifying a 'Turkish-looking man' as cycling near the vicinity of the crime. For the public prosecutor, the relationship between this first investigative witness description and the eventual DNA identification is clear. Both point to the 'same' suspect, with the latter simply being more granular and precise than the first. In so doing the prosecutor maps phenotypical and biological differences onto each other, suggesting that the surface of the body testifies to a genetic truth hiding within. A genetic truth, furthermore, uncovered by the ever-more precise forensic DNA research: first biogeographic ancestry, detailing a migration history that Hüseyin A. shared, then familial DNA, showing the similarity between the offender DNA and that of Hüseyin A.'s brother, and finally, the truly individualized DNA match. Here, then, the differences and non-coherences between these suspect collectives are tamed and hierarchized in an appeal to every greater precision. In so, thus, connecting and mapping these different collectives, however, the public prosecutor comes very close to reproducing a specific understanding of race, in which the body surface is taken as a sign of a deeper biological truth. Here, these multiple collectives run the risk of indeed congealing into race. 
The Court, however, elects a different strategy of relating these non-coherent collectives in its final verdict. While it does find Hüseyin A. guilty, it does not follow the prosecutor in its construction of the evidence. The difference between the two narratives pivots on the Court's treatment of the initial witness description: while the prosecutor uses it as an additional piece of evidence demonstrating Hüseyin A.'s guilt, the Court treats it differently. Trying less to use all available evidence to make a case against Hüseyin A., it treats that first witness description not as evidence of Hüseyin A.'s guilt, but rather mobilizes it to highlight the truth of the very first statement Hüseyin A made to the police in 1992, in which he said he had indeed cycled on that street that night-which is a statement he later retracted. Hence, the phenotypical witness description does not function as the first step in an ever-more granular process of identification - as it does for the prosecutor-but merely as an indication that whatever else Hüseyin A. said in that very first statement to the police was true. Here, non-coherence is managed through erasure: by treating the witness description only as evidence of the truth of Hüseyin A first statement to the police, not as an evidentiary method of identification, the Court erases the witness description's particular mode of enacting differences, rendered superfluous. Perhaps the Court did not need this identification, having at its disposal the final match between Hüseyin A's DNA and that found at the crime scene. Perhaps-and here we are speculating - it found this witness description not a strong enough form of evidence to mobilize in support of Hüseyin A's guilt. In that case, these judges would not be the first to approach witness descriptions involving phenotypical markers and identifications with some caution. After all, such phenotypical witness accounts tend to raise difficult questions about how ethnic or racial difference are seen and registered by different people to be begin with and the kind of 'visual expertise' such judgments would entail — questions judges, we know from previous research (van Oorschot 2021) do not always feel equipped to tackle in their courts.

\section{Keeping race at bay: forensic technologies, fractured realities, and care}

Zooming out from this case, we can draw out both conceptual and methodological lessons. First, this examination of the ways forensic and police investigators mobilized familial DNA searching offers conceptual tools to attend to the more general use and circulation of novel forensic technologies. As we demonstrate, specific investigative and identification technologies come with specific affordances, as well as with legal, ethical, and pragmatic problems attached. Our case illustrates the work that goes into managing these novel affordances and limitations, not only at the legal level (with the adoption of the 2012 law), but also and especially at the level of forensic and police practice. While forensic technologies, in their promissory capacity, may be quick to mobilize interest, they must nevertheless be carefully calibrated. Such calibration practices are both legal, technical, and as we have seen, societal and political as well. In such processes, the stakes are very high: not only is there the possibility of reinforcing ethic and racial discrimination, but also-from the perspective of investigating actors - the possibility of endangering the future uses of the technology. Here, our insights resonate in particular with those approaches 
to forensic technologies that show that their 'adoption' in practice is not a smooth or uncontested process (Toom 2010; Hopman et al. forthcoming; Wienroth 2018; Lynch et al. 2008; Hindmarsh and Prainsack 2010), and that explicit concerns with future uses and possibilities shape the way forensic and legal actors mobilize them in practice. Our insights, however, also demonstrate that broader concerns with race and racism inform both their academic reception and practical take-up. Here, the racializing potential of such technologies is refracted through a lens of 'stigmatization' of specific communities, and-as we have shown-significantly shaped both investigative and communication strategies.

However, these data also resonate with studies highlighting the introduction, translation and use of technologies that rely on the production of collectives in other settings. In medical settings, for instance, we know that race-based diagnostics play a particularly controversial role (Kahn 2012): on the one hand, they may be celebrated as the first step in the direction of a future of full individualization-in which race functions as a proxy for individual differences-yet on the other they also generate novel epistemological as well as ethical dilemmas in the here and now. There, too, genomics has required new modes of caring to be invented, as patients and medical professionals actively aim to manage the dangers of stigmatization that co-emerge with genetics and risk-based thinking (Bliss 2012; Pollock 2012), and solidarities are reshaped (Van Hoyweghen and Rebert 2012; Prainsack and Van Hoyweghen 2020). Tracing specific modes of managing non-coherent collectives across scales and settings, then, is one way to attend to the both translation of, and resistance to, the novel forms of 'doing collectives' that accompany new genetic technologies.

A second conceptual point to draw out here is how our examination of this specific case helps underline the multiple and fractured realities of race itself. Important studies of the role of biological difference in genetic and forensic contexts have demonstrated that, in varying shapes or forms, race persists (M'charek 2014; Fortier 2011; Koenig et al. 2008). Yet they also show that it may persist precisely because it stays, so to say, 'underground,' implicit in technologies and infrastructures. There, it exists as a specter that 'haunts' practices (M'charek and van Oorschot 2019), a ghost that needs to be deferred and avoided at all costs. Techniques of evading race may be temporal, for instance when geneticists promise to take us beyond old race sciences into a future of granular, specific, and individualized genetic information, in which racial categories are presented as necessary 'in the meantime' before a promised future of full individualization (Kahn 2012). Or race may be displaced-kept at bay-spatially, when, e.g., the very categories that shape sampling procedures, for instance, are delegated the status of largely unremarked-upon research and dataset infrastructure (M'charek 2014, Cf Star 1999) and as such become absent presences. These scientific techniques of displacement may be more or less successful in 'keeping race at bay.' Importantly, however, we have shown that such techniques are not found only in scientific practices. Indeed, our case shows that police investigators themselves sought to keep race at bay. While on the one hand they made relations between these multiple collectives - using biogeographic ancestry data in order to arrive at a specific sample for the later familial DNA searching-they also had to actively undo such relations. Individualized communication, outreach, and sampling strategies were crucial here-much like the public transparency offered by 
an intensively managed communication and outreach campaign, spearheaded by the Dutch crime-watch Opsporing Verzocht. As such, this fractured reality of race also turns out to be a pragmatic and ethical asset for certain actors: keeping these fragments in play, these collectives never quite managed to congeal into 'race' (except in the public prosecutor's strategy of taming these non-coherent collectives). Our analysis, then, resonates with a wealth of studies that point to the situated, non-stable, and absent-present character of race. Crucially, what our analysis adds to this understanding of race is that we show how actors beyond the lab pragmatically and carefully make use of this particular fractured character of race.

In so doing, we have made the deliberate effort to cast our analysis in a register of care as well. While critique has been a dominant approach to race-and for good reason! - it tends to unify and reify its object—race-and as such runs the risk of blinding us to precisely the non-coherences that are always already present when it comes to race. Indeed, 'race' is itself an unstable thing (Hall 1987) and 'moving target' (Hacking 2007), with the static raciological typifications of the nineteenth centuries having their more dynamic precursors in environmental, even humoralist understandings of race (Willoughby 2017). Nor was race ever completely about biology alone; indeed, M'charek (2020) points out that at stake in such nineteenth century knowledge practices was always much more than the biological body, such as dress, facial hair, etc. Race, then, has in various ways always been a hybrid, perched uncomfortably on the distinctions between nature and culture, 'bad' science and 'good' science, pasts and the futures. And while race may acquire a certain rigidity and fixedness in certain contexts, this rigidity is not given. Carefully untangling where something is made into race, where race hides in the shadows as an absent presence, or where it is actively suppressed, denied, displaced, or erased is a productive mode of engaging with race precisely because it demonstrates the contingent, non-coherent character of race itself. Here we may venture, then, a methodological lesson, or rather a methodological invitation: is it possible, for us, to extend care to the very category of race itself (Cf. M'charek forthcoming)? Such care, we learn from Puig de la Bellacasa (2017) is not a moral stance or stamp of approval, but rather a willingness to attend to it closely, to get one's hands dirty, and to oblige ourselves to care-full empirical work in its presence. Perhaps this piece, closely attending to the non-coherencies of difference and analyzing how police investigators manage these non-coherencies, is best read as a step in that direction.

Acknowledgements The authors wish to thank the editors of this special issue, especially Anne Pollock, for their support throughout the conception, writing and publication of this article. We also thank Lisette Jong, Roos Hopman and Peter de Knijff for valuable conversations about the case. Finally, this work is indebted to the support of the ERC, as the article was written in the context of the RaceFace ID Consolidator grant ( FP7-617451- RaceFaceID-Race Matter: On the Absent Presence of Race in Forensic Identification).

\section{Declarations}

Conflict of interest On behalf of all authors, the corresponding author states that there is no conflict of interest. 
Open Access This article is licensed under a Creative Commons Attribution 4.0 International License, which permits use, sharing, adaptation, distribution and reproduction in any medium or format, as long as you give appropriate credit to the original author(s) and the source, provide a link to the Creative Commons licence, and indicate if changes were made. The images or other third party material in this article are included in the article's Creative Commons licence, unless indicated otherwise in a credit line to the material. If material is not included in the article's Creative Commons licence and your intended use is not permitted by statutory regulation or exceeds the permitted use, you will need to obtain permission directly from the copyright holder. To view a copy of this licence, visit http://creativecommons.org/licen ses/by/4.0/.

\section{References}

Balkenhol, M., P. Mepschen, and J.W. Duyvendak. 2016. The nativist triangle: Sexuality, race, and religion in discourses on dutchness. In The Culturalization of Citizenship: Autochthony and Belonging in a Globalized World JW Duyvendak, ed. P. Geschiere and E. Tonkens, 97-116. London: Palgrave MacMillan.

Bliss, C. 2012. Race decoded: The genomic fight for social justice. Stanford: Stanford University Press.

Cole, S.A. 2020. Individual and collective identification in contemporary forensics. BioSocieties 15 (3): 350-375.

Cole, S.A., and M. Lynch. 2006. The social and legal construction of suspects. Annual Review of Law and Social Science 2(1): 39-60

de Knijff, P. 2006. Meehuilen met de Wolven? Inaugural lecture: Leiden University.

De Volkskrant, 12 December 2018. 'Hoe de politie na 25 jaar alsnog de moord of Milica van Doorn kon oplossen.' E Stoker. https://www.volkskrant.nl/nieuws-achtergrond/hoe-de-politie-na-25-jaar-dezaak-milica-van-doorn-alsnog-kon-oplossen b2a42503/. Accesed 8 August, 2019

de Rooij, M., R. van Reekum, and A M'charek, . 2014. Tijdspraktijken: DNA en de On/Onderbroken Stad. Sociologie 10 (3/4): 319-337.

Du Bois, W.E.B. 1940. Dusk of dawn. San Diego: Harcourt, Brace and Company.

Duster, T. 2006. The molecular reinscription of race: Unanticipated issues in biotechnology and forensic science. Patterns of Prejudice 40 (4/5): 427-441.

Essed, P., and I. Hoving. 2014. Dutch racism. Leiden: Brill Publishing.

Fortier, A.M. 2011. Genetic indigenisation in 'The People of the British Isles'. Science as Culture 21(2): 153-175.

Foster, M.W., and R.R. Sharp. 2002. Race, ethnicity, and genomics: Social classifications as proxies of biological heterogeneity. Genome Research 12 (6): 844-850.

Fujimura, J., and R. Rajagopalan. 2011. Different differences: The use of "Genetic Ancestry testing" versus race in biomedical human genetics. Social Studies of Science 41(1)

Fullwiley, D. 2007. The molecularization of race: Institutionalizing human difference in pharmacogenetics practice. Science as Culture 16(1):1-30.

Gannett, L. 2014. Biogeographical ancestry and race. Studies in History and Philosophy of Biological and Biomedical Sciences 47: 173-184.

Goodman, A.H., Y.T. Moses, and J.L. Jones. 2012. Race: Are we so different? Chichester: Wiley-Blackwell.

Hacking, I. 2007. Kinds of people: Moving targets. Proceedings of the British Academy 151: 285-318.

Hall, S. 1987 'Minimal selves' Identity: The Real Me L. Appignanesi, ICA, London

Haraway, D. 1991 A Cyborg Manifesto: Science, technology, and socialist-feminism in the late twentieth century. Simians, Cyborgs, and Women: The Reinvention of Nature, 149-181. New York: Routledge

Haraway, D. 2016. Staying with the trouble: Making kin in the Chthulucene. Durham: Duke University Press.

Hartigan, J. 2008. Is race still socially constructed? The Recent Controversy over Race and Medical Genetics'. Science as Culture 17 (2): 163-193.

Hindmarsh, R., and B. Prainsack. 2010. Genetic suspects: global governance of forensic profiling and databasing. Cambridge: Cambridge University Press. 
Hopman, R., I. van Oorschot, and A. M'charek. (forthcoming) From promise to practice: Anticipatory work and theadoption of massive parallel sequencing in forensics. In Techno-Legal worlds, ed. V. Toom, M. Wienroth, and A.M'charek. London: Routledge.

Jong, L., and A. M'charek. 2018. The high-profile case as 'fire object': Following the Marianne Vaatstra murder case through the media. Crime, Media, Culture 14 (3): 347-363.

Kahn, J. 2012. Race in a bottle: The story of BiDil and racialized medicine in a post-genomic age. New York: Columbia University Press.

Kayser, M. 2015. Forensic DNA phenotyping: Predicting human appearance from crime scene material for investigative purposes. Forensic Science International: Genetics 18: 33-48.

Koenig, B.A., S.S.J. Lee, and S.S. Richardson. 2008. Revisiting race in a genomic age. New Brunswick, N.J: Rutgers University Press.

Latour, B., and C. Porter. 1993. We have never been modern. Cambridge MA: Harvard University Press.

Law, J., G. Afdal, K. Asdal, W. Lin, I. Moser, and V. Singleton. 2014. Modes of syncretism: Notes on noncoherence. Common Knowledge 20 (1): 172-192.

Lipphardt, V. 2017. The body as a substrate of differentiation. Shifting the focus from race science to life scientists' research on human variation. Varia Historia 33(61): 109-133

Lynch, M., S.A. Cole, R. McNally, and K. Jordan. 2008. Truth machine: The contentious history of DNA fingerprinting. Chicago: University of Chicago Press.

Machado, H., and R. Granja. 2020. Emerging DNA technologies and stigmatization. In Forensic genetics in the governance of crime, ed. H. Machado and R. Granja. Singapore: Palgrave MacMillan.

M'charek, A. 2000. Technologies of population: Forensic DNA testing practices and the making of differences and similarities. Configurations 8: 121-159.

M'charek, A. 2005. The human genome diversity project: An ethnography of scientific practice. Cambridge: Cambridge University Press.

M'charek, A. 2013. Beyond fact or fiction: on the materiality of race in practice. Cultural Anthropology 28 (3): 420-442.

M'charek, A. 2014. Race, time and folded objects: The HeLa error. Theory, Culture and Society 31 (6): 29-56.

M'charek, A. 2020. Tentacular faces: Race and the return of the phenotype in forensic identification. American Anthropologist 122: 369-380.

M'charek, A. (forthcoming) Caring for the object: Forensics, Face, and Generous Methods for Studying Race. In Social Studies of Science, special issue Race, Face, Forensics. eds. A. M'charek and I. van Oorschot.

M'charek, A., and I. van Oorschot. 2019. What about race? In Routledge companion to Actor-Network theory, ed. London: Routledge.

M'charek, A., and P. Wade. 2020. Doing the individual and the collective in forensic genetics: Governance race and restitution. BioSocieties 15 (3): 317-328. https://doi.org/10.1057/s41292-020-00193-6.

M'charek, A., V. Toom, and L. Jong. 2020. The trouble with race in forensic identification. Science, Technology, \& Human Values 45 (5): 804-828.

Mol, A. 2002. The body multiple: Ontology in medical practice. Durham: Duke University Press.

Nash, C. 2005. Geographies of relatedness. Transactions of the Institute of British Geographers 30: $449-462$.

Nelson, A. 2008. Bio science: Genetic genealogy testing and the pursuit of african ancestry. Social Studies of Science 38: 759-783.

NOS, 16 July 2016. 'Gulen-beweging achter Turkse Coup? “Zeer onwaarschijnlijk”,. https://nos.nl/artik el/2118021-gulen-beweging-achter-turkse-coup-zeer-onwaarschijnlijk.html. Accesed 8 Aug 2019.

Ossorio, P.N. 2006. About face: Forensic genetic testing for race and visible traits. Journal of Law and Medical Ethics. 34 (2): 277-292.

Palmié, S. 2007. Genomics, divination, "racecraft.” American Ethnologist 34 (2): 205-222.

Pollock, A. 2012. Medicating race: Heart disease and durable occupations with difference. Durham: Duke University Press.

Prainsack, B., and I. Van Hoyweghen. 2020. Shifting solidarities: Personalisation in insurance and medicine. In: Shifting solidarities. Trends and developments in European societies, ed. I. Van Hoyweghen, V. Pulignano, and G. Meyers. New York: Palgrave Macmillan.

Puig de la Bellacasa, M. 2017. Matters of care: Speculative ethics in more than human worlds. Minneapolis: University of Minnesota Press.

Rabinow, P., and N. Rose. 2006. Biopower today. BioSocieties 1: 195-217 
Reardon, J. 2005. Race to the finish: Identity and governance in an age of genomics. Princeton: Princeton University Press.

Reardon, J., and K. TallBear. 2012. "Your DNA is our history": Genomics, anthropology, and the construction of whiteness as property. Current Anthropology 53 (5): 233-245.

Santos, R.V., and M.C. Maio. 2004. Race, genomics, identities and politics in contemporary Brazil. Critique of Anthropology 24 (4): 347-378.

Star, S.L. 1999. The ethnography of infrastructure. American Behavioral Scientist 43 (3): 377-391.

Toom, V. 2010. Dragers van Waarheid: Normatieve Aspecten van 20 jaar DNA onderzoek in Nederland. Kluwer.

Toom, V., and A. M'charek. 2011. Van individuele verdachte naar verdachte families en populaties: Het wegen van nieuwe forensische DNA-technieken. Nederlands Juristenblad 86 (3): 142-148

Van Hoyweghen, I., and L. Rebert. 2012. Your genes in insurance: From genetic discrimination to genomic solidarity. Personalized Medicine 9 (8): 871-877.

Van Oorschot, I. (2014a). Het dossier-in-actie: Vouw- en ontvouwpraktijken in juridische waarheidsvinding. Sociologie 10 (3/4), 301-318.

Van Oorschot, I. 2014b. Seeing the case clearly: File-work, material mediation and visualizing practice in a Dutch criminal court. Symbolic Interaction, 37 (4): 439-457.

Van Oorschot, I. 2018. Doing times, doing truths: The legal case file as a folded object. In Regulating time, ed. E. Grabham and S. Beynon-Jones. Social Justice Series, Routledge.

van Oorschot, I. 2020. Culture, Milieu, phenotype: Articulating race in judicial sense-making practices. Social \& Legal Studies 29 (6): 790-811. https://doi.org/10.1177/0964663920907992

van Oorschot, I. 2021. The law multiple: Judgment and knowledge in practice. Cambridge: Cambridge University Press.

Van Oorschot, I., and A. M'charek. forthcoming. Un/doing race: On technology, individuals, and collectives in forensic practice. In The handbook for the anthropology of technology, ed. M. Hojer-Bruun and C. Hasse. London: Palgrave MacMillan.

Van Reekum, R. 2014. Out of character: Debating dutchness, narrating citizenship. Dissertation, University of Amsterdam.

Wade, P., V.G. Deister, M. Kent, M.F. Olarte Sierra, and A.D. del Castillo Hernández. 2014. Nation and the absent presence of race in Latin American genomics. Current Anthropology 55 (5): 497-522. https://doi.org/10.1086/677945.

Walker, B.A. 2003. The color of crime: The case against race based suspect descriptions. Columbia Law Review 103 (3): 662-688.

Wekker, G. 2016. White innocence: Paradoxes of colonialism and race. Durham: Duke University Press.

Wienroth, M. 2018. Governing anticipatory technology practices. Forensic DNA Phenotyping and the Forensic Genetics Community in Europe. New Genetics and Society 37 (2): 137-152.

Willoughby, C.D. 2017. "His native, hot country": Racial science and environment in antebellum American medical thought. Journal of the History of Medicine and Allied Sciences 72 (3): 328-351.

Wissink, L., and I. van Oorschot. 2021. Affective bureaucratic relations: File practices in a European deportation unit and criminal court. Environment and Planning C: Politics and Space 39 (5): 10491065. https://doi.org/10.1177/2399654420977475.

Publisher's Note Springer Nature remains neutral with regard to jurisdictional claims in published maps and institutional affiliations.

Irene van Oorschot is a Marie Curie IF scholar at the Life Sciences and Society Lab, KU Leuven. Her research concentrates on practices of knowing and valuation in diverse settings. Recently, she published The Law Multiple: Judgment and Knowledge in Practice (Cambridge University Press).

Amade M'charek is a Professor of Anthropology of Science at the Department of Anthropology, University of Amsterdam. She is the PI of the RaceFaceID project, an ERC-consolidator project on forensic identification and the making of face and race. Her work centers on the ir/relevance of race in science and society. She has published widely on genetic diversity, population genetics, and forensic DNA practices, as well on biomedical practices. Through her current research on forensics and migrant death, she has developed an interest into (post)colonial relations, circulations, and extractions. 